\title{
Anticancer potential of selected Fallopia Adans species
}

\author{
OCTAVIAN TUDOREL OLARU ${ }^{1 *}$, LUANNE VENABLES $^{2 *}$, MARYNA VAN DE VENTER $^{2 *}$, \\ GEORGE MIHAI NITULESCU $^{1 *}$, DENISA MARGINA ${ }^{1 *}$, \\ DEMETRIOS A. SPANDIDOS ${ }^{3}$ and ARISTIDIS M. TSATSAKIS ${ }^{4}$
}

\author{
${ }^{1}$ Faculty of Pharmacy, 'Carol Davila' University of Medicine and Pharmacy, Bucharest 020956, Romania; \\ ${ }^{2}$ Department of Biochemistry and Microbiology, Nelson Mandela Metropolitan University, Port Elizabeth 6031, South Africa; \\ ${ }^{3}$ Department of Clinical Virology, School of Medicine, ${ }^{4}$ Department of Forensic Sciences and Toxicology, \\ Faculty of Medicine, University of Crete, Heraklion 71003, Greece
}

Received June 4, 2015; Accepted July 2, 2015

DOI: $10.3892 / \mathrm{ol} .2015 .3453$

\begin{abstract}
The aim of the present study was to determine the anticancer potential of three species belonging to the Fallopia genus (Polygonaceae): Fallopia convolvulus (F. convolvulus, Fallopia dumetorum (F. dumetorum) and Fallopia aubertii (F.aubertii). For this purpose, crude extracts were obtained and characterized for their phenolic and flavonoid total content and examined for their anticancer activity on three tumor cell lines: breast cancer (MCF7), colon carcinoma (Caco-2) and cervical cancer (HeLa) cells. The cytotoxic potential of the three species was assessed by MTT assay, cell cycle analysis and by the evaluation of mitochondrial membrane potential (MMP). The acute toxicity of the extracts was evaluated using one in vitro cell model (Vero cells, an African Green monkey kidney cell line) and two invertebrate in vivo models (Daphnia magna and Artemia salina). The highest total phenolic and flavonoid content was found in the $F$. aubertii flower extracts. The cytotoxic effects of the extracts from $F$. aubertii and $F$. convolvulus on all three cell lines were examined at concentrations ranging from 3 to $300 \mu \mathrm{g} / \mathrm{ml}$. G2/M cell cycle arrest was induced by all the extracts, and a significant increase in the subG1 cell population was observed. The hydroethanolic extract from the flowers of $F$. aubertii induced cell apoptosis more rapidly than the other extracts. The MMP indicates the involvement
\end{abstract}

Correspondence to: Professor George Mihai Nitulescu, Faculty of Pharmacy, 'Carol Davila' University of Medicine and Pharmacy, Traian Vuia 6, Bucharest 020956, Romania

E-mail: nitulescu_mihai@yahoo.com

${ }^{*}$ Contributed equally

Abbreviations: DM, dry material; DMSO, dimethyl sulfoxide; JC-1, 5,5',6,6'tetrachloro-1,1',3,3'-tetraethylbenzimidazol-carbocyanine iodide;MMP,mitochondrialmembranepotential;MTT,3-(4,5-dimethyl1,3-thiazol-2-yl)-2,5-diphenyl-2H-tetrazoliumbromide;PBS,phosphatebuffered saline; TFC, total flavonoid content; TPC, total phenolic content

Key words: flavonoids, apoptosis, mitochondrial membrane potential, cell cycle analysis, invertebrate bioassays of the mitochondria in the induction of apoptosis. A positive correlation between the total phenolic content of the extracts and the $\mathrm{IC}_{50}$ values against the HeLa cells was also noted. None of the extracts exhibited significantly toxic effects. Considering the antitumor potential of $F$. aubertii and $F$. convolvulus, these two species may represent a good source of plant extracts with anticancer properties.

\section{Introduction}

Cancer is the main cause of mortality and morbidity in Europe following cardiovascular diseases and represents the uncontrolled growth and spread of cells that arises from a change in one single cell (1). Each year, millions of individuals are diagnosed with cancer. The disease accounts for the death of approximately 3.5 million individuals annually worldwide (2). It was estimated that only in Europe, in 2012, 3.45 million new cases of cancer were noted, excluding non-melanoma skin cancer, and 1.75 million deaths occurred from cancer (3).

Throughout history, plant extracts and their purified active components have been the backbone of cancer chemotherapeutics (4). Additionally, structural analogues have been obtained by molecular modifications of the natural compounds and have reinforced the anticancer arsenal (5). It is estimated that over $70 \%$ of anticancer compounds are either natural products, or natural product-derived substances (6). The rich diversity of the chemical structures provided by natural resources offers valuable templates for exploring novel molecular scaffolds and is the most significant source of new drug developments (7).

Over the past two decades, flavonoid-rich plant extracts and isolated flavonoids have shown anticancer potential (8). Apigenin, baicalein, luteolin, nobiletin and tangeretin have been shown to be the most effective flavonoids against carcinomas of the stomach, whereas luteolin has been shown to be a promising candidate for the treatment of skin cancer $(9,10)$. Hesperidin has been shown to inhibit human pancreatic cancer cell growth and its use has been suggested for the prevention of pancreatic cancer (11). A number of targets and a variety of action mechanisms have been proposed to explain the cytotoxic effects of flavonoids. Genistein, daidzein, luteolin and quercetin are able to inhibit DNA topoisomerase activity 
and are considered as potential agents for future use in cancer therapeutics (12). Quercetin, luteolin and kaempferol are promising antitumor agents that can block the cell cycle (13), induce apoptosis (14), inhibit angiogenesis (15) and modulate the epxression of several protein kinases (16). Fisetin acts as a dual inhibitor of the phosphatidylinositol 3-kinase (PI3K)/ Akt and mammalian target of rapamycin (mTOR) pathways and has been evaluated for its potential inhibitory role against in vitro (17). Myricetin and quercetagetin have been shown to inhibit the activity of PI3Ks (18). Given the high antitumor potential of these compounds, a number of plant extracts rich in flavonoids have been investigated in order to evaluate their anticancer properties $(19,20)$. The low production cost of the plant extracts compared to the pure compounds and the synergistic effects of the natural compounds are the main advantages for using natural extracts (21).

Fallopia Adans is a plant genus which contains approximately 15 species (22-24). The species are widespread over the northern hemisphere (25). With the exception of Fallopia japonica (Houtt.) Ronse Decr. (syn. Polygonum cuspidatum) and Fallopia multiflora (Thunb.) Haraldson, the therapeutic potential of all the other species has not been investigated in detail (26). These plants are invasive and can easily produce biomass and can therefore be introduced in crops (27). Fallopia convolvulus (F. convolvulus) (L.) Á. Löve and Fallopia dumetorum (F.dumetorum) (L.) Holub (syn. Polygonum dumetorum L.) are native to Europe, and Fallopia aubertii (F.aubertii) (L. Henry) Holub [syn. Fallopia baldschuanica (Regel) Holub] is a subspontaneous species introduced from Central Asia as an ornamental plant (25). Chemotaxonomic studies on the genus Fallopia have shown that all species contain flavonoids with a profile relatively uniform for all species and that quercetin glycosides are the major constituents $(28,29)$. The flavonoid fraction of $F$. convolvulus consist of glycosides of quercetin, kaempferol, myricetin, apigenin, luteolin, rhamnetin and isorhamnetin $(28,30)$. Three characteristic flavonoid structures have also been found in this species: falloconvolin $\mathrm{A}$ and $\mathrm{B}$ and quercetin-3-O-(2-E-esinapoxyl)-glucopyranoside (31). In $F$. aubertii, glycosides of quercetin, kaempferol, apigenin, luteolin, myricetin and several chromones structures have been identified $(29,32,33)$. With the exception of rhamnetin, isorhamnetin and characteristic flavonoids, all other flavonoids have also been found in F. dumetorum (28).

The aim of this study was to examine the effects of various plant extracts from three Fallopia species, F. convolvulus, $F$. dumetorum and $F$. aubertii, on cancer cell lines in order to further determine their usefulness. The correlations between the polyphenol and flavonoid content and the cytotoxic effects of these extracts were also evaluated.

\section{Materials and methods}

Materials. Folin-Ciocalteau reagent, methanol p.a., ethanol p.a., potassium acetate $\left(\mathrm{CH}_{3} \mathrm{COOK}\right)$, quercetin trihydrate, colchicine and dimethyl sulfoxide (DMSO) were purchased from SigmaAldrich Chemie GmbH (Steinheim, Germany). Aluminium chloride hexahydrate $\left(\mathrm{AlCl}_{3} \times 6 \mathrm{H}_{2} \mathrm{O}\right)$, sodium carbonate anhydrous $\left(\mathrm{Na}_{2} \mathrm{CO}_{3}\right)$ and gallic acid were purchased from Scharlau Co. (Barcelona, Spain). Cervical cancer (HeLa) and colon cancer (Caco-2) cells were purchased from Cellonex,
Separations (Randburg, South Africa) and breast (MCF7) cancer cells were purchased from Highveld Biological (Johannesburg, South Africa). The Coulter ${ }^{\circledR}$ DNA Prep ${ }^{\mathrm{TM}}$ reagents kit was purchased from Beckman Coulter (Fullerton, CA, USA). 3-(4,5-Dimethyl-1,3-thiazol-2-yl)-2,5-diphenyl2H-tetrazolium bromide (MTT) and 5,5',6,6'tetrachloro1,1',3,3'-tetraethylbenzimidazol-carbocyanine iodide (JC-1) were purchased from Sigma (St. Louis, MO, USA). Dulbecco's modified Eagle's medium (DMEM) and fetal bovine serum (FBS) was purchased from Thermo Scientific (Logan, UT, USA).

Plant material and preparation of the extracts. F. convolvulus was harvested from Buftea, Ilfov county (July, 2013), F. dumetorum from Zimnicea, Telorman county (June, 2013) and $F$. aubertii from Bucharest (October, 2013) Romania. The identity was established by comparing with herbarium specimens from 'Dimitrie Brandza' Botanical Garden, Bucharest and voucher specimens are available in the herbarium collection of the Department of Botany and Cell Biology, 'Carol Davila' University of Medicine and Pharmacy, Bucharest, Romania. F. convolvulus (C) and F. dumetorum (D) consisted of stems, leaves, flowers and fruits and, F. aubertii consisted of flowers (AF), and stems and leaves (AH). A total of $10 \mathrm{~g}$ of each material was grounded (mesh 14) and extracted with 3x100 ml solvent (e, ethanol; ha, ethanol 50\%; w, water) under reflux, followed by concentration (rotary evaporator, RVO 004; Ingos, Prague, Czech Republic) and lyophilized at $-55^{\circ} \mathrm{C}$ (CoolSafe ScanVac 55; LaboGene, Lynge, Denmark). For the cell culture experiments, plant extracts $\left(\mathrm{AF}_{\mathrm{ha}}, \mathrm{AF}_{\mathrm{e}}, \mathrm{AF}_{\mathrm{w}}\right.$ and $\left.\mathrm{AH}_{\mathrm{ha}}\right)$, were reconstituted in DMSO at a final concentration of $100 \mathrm{mg} / \mathrm{ml}$ and stored at $-20^{\circ} \mathrm{C}$ until use. Serial dilutions were prepared in order to obtain the following concentrations: 3, 30, 100 and $300 \mu \mathrm{g} / \mathrm{ml}$.

Phytochemical determinations. The total polyphenol content (TPC) was determined according to the Folin-Ciocalteu method described by González et al (34) (at $\lambda=750 \mathrm{~nm}$ ) and the total flavonoid content (TFC) was determined using the method with $\mathrm{AlCl}_{3}$ as described by Chang et al (35) and Bazylko et al (at $\lambda=429 \mathrm{~nm}$ ) (36). All determinations were performed in triplicate and were measured using a UV-VIS spectrophotometer (Halo DB-20-220; Dynamica, Salzburg-Mayrwies, Austria).

The results were calculated using linear calibration curves and are expressed as the means \pm SEM of the experiments in milligram gallic acid equivalents (GA equiv.) per gram of dry material (DM) and in milligram quercetin equivalents (Q equiv.) per gram of DM.

\section{Assessment of toxicity}

In vitro screening of the extracts for their potential cytotoxicity on cancer cell lines. The human cancer cell lines, MCF7 (breast cancer), Caco-2 (colon carcinoma) and HeLa (cervical cancer), were used for the screening process. All cell lines were grown in DMEM supplemented with $10 \%$ fetal bovine serum. Each cell line was seeded in $200 \mu \mathrm{l}$ aliquots at a cell density of $3 \times 10^{4}$ cells $/ \mathrm{ml}$ in 96-well plates and left overnight to attach. For the treatment of each cell line, the medium was replaced with fresh medium containing four concentrations $(3,30,100$ and $300 \mu \mathrm{g} / \mathrm{ml})$ of extract. The treated cells were incubated at $37^{\circ} \mathrm{C}$ in a humidified $5 \% \mathrm{CO}_{2}$ incubator for $48 \mathrm{~h}$. 
The medium containing the various treatments was removed prior to the addition of MTT solution to the cells and replaced with $200 \mu \mathrm{l}$ of medium containing $0.5 \mathrm{mg} / \mathrm{ml}$ MTT. The cells were incubated for $3 \mathrm{~h}$. Thereafter, the medium was removed and the blue formazan product was solubilized in DMSO. The absorbance was read at $540 \mathrm{~nm}$ using a BioTek ${ }^{\circledR}$ PowerWave XS spectrophotometer (BioTek, Winooski, VT, USA).

Optical density (OD) data were analyzed using Excel and the relative cell viability was determined using quadruplicate readings. Untreated cells were considered to have $100 \%$ cell viability. Cell viabilities in other test wells were calculated relative to the untreated controls and expressed as a percentage.

Due to the positive correlation between the concentration sued and the biological effects, HeLa cells were used for the determination of the $\mathrm{IC}_{50}$ value of the cytotoxicity of the Fallopia extracts. HeLa cells were seeded in the same manner as described above for the initial screening protocol. The cells were treated with various concentrations of plant extract (12.5$500 \mu \mathrm{g} / \mathrm{ml}$ ) and exposed to the extract for $48 \mathrm{~h}$. In the same manner as described above for the initial screening protocol, MTT was used to determine cell viability following incubation.

Evaluation of toxicity using a normal cell model in vitro. Extracts exhibiting cytotoxicity were tested against a normal cell line. Vero cells (an African green monkey kidney cell line) were used and seeded at a density of $1 \times 10^{5}$ cells $/ \mathrm{ml}$. The determination of the cytotoxicity was performed according to the protocol described above.

Assessment of acute toxicity. The assessment of acute toxicity was determined using two different assays as follows:

i) Artemia salina toxicity assay. Brine shrimp (Artemia salina L.) lethality assay was performed using the procedures described in the study by Meyer et al (37) with some modifications. Brine shrimp cysts were obtained from a local aquarium (Bucharest, Romania) and incubated in artificial sea water (40 g/l salinity) for $24 \mathrm{~h}$ in a growth chamber (Sanyo MLR-351H; Sanyo, San Diego, CA, USA) at $25 \pm 1^{\circ} \mathrm{C}$, under continuous aeration, using a 16-h photoperiod and $8 \mathrm{~h}$ of darkness. The newly hatched nauplii were separated from the shells, transferred to fresh sea water with a micropipette and incubated for $24 \mathrm{~h}$. Assays were performed in Petri dishes $(\mathrm{d}=30 \mathrm{~mm})$. Each dish contained 20 larvae in a final volume of 2,000 $\mu \mathrm{l}$. The plant extract concentrations were in the range of 1,000-3,000 $\mu \mathrm{g} / \mathrm{ml}(1,000,1,500,2,000,2,500$ and $3,000 \mu \mathrm{g} / \mathrm{ml})$ and the final DMSO concentration was $1 \%(\mathrm{v} / \mathrm{v})$. A solution of $1 \%$ DMSO in artificial seawater was used as a negative control and colchicine in the range of $0.5-10 \mu \mathrm{g} / \mathrm{ml}$ as a positive control. The concentrations were selected after no lethality was registered during a preliminary test using plant extracts at concentrations of 1-1,000 $\mu \mathrm{g} / \mathrm{ml}$. Each sample was performed in duplicate and each test was run twice. Due to the absence of specific information about the stability of the plant extracts in the presence of light, the bioassay was performed in the dark. After $24 \mathrm{~h}$, the number of survivign organisms was counted and recorded. Larvae were considered dead only if they did not move their appendages for $10 \mathrm{sec}$ during observation.

ii) Daphnia magna toxicity assay. Daphnia magna Straus were maintained parthenogenetically at 'Carol Davila' University (Department of Pharmaceutical Botany and Cell
Biology) from 2012. Prior to the assay, the daphnids were selected according to their size and kept in fresh water under continuous aeration. The bioassay was performed according to the method described in the study by Fan et al (38) with some modifications (39). Ten daphnids were inserted in $10 \mathrm{ml}$ graduated test tubes, and the plant extracts were added in synthetic media in order to obtain solutions of $1,000,1,500$, 2,000, 2,500 and 3,000 $\mu \mathrm{g}$ extract $/ \mathrm{ml}$. The final test solutions were $1 \%$ DMSO concentration/10 ml final volume. Synthetic medium with $1 \%$ DMSO was used as a negative control and colchicine as a positive control. The daphnids were kept under the same conditions as those described above for the Artemia salina assay and the number of surviving daphnids was counted after $24 \mathrm{~h}$. Each sample was performed in duplicate and each test was run twice. The daphnids were considered dead only if they did not move their appendages for $30 \mathrm{sec}$ during observations.

Cell cycle analysis. HeLa cells were seeded at $5 \times 10^{4}$ cells $/ \mathrm{ml}$ in $10 \mathrm{ml}$ aliquots in $10 \mathrm{~cm}$ culture dishes and treated with $\mathrm{IC}_{50}$ values of $\mathrm{AF}_{\mathrm{ha}}, \mathrm{AF}_{\mathrm{e}}$ and $\mathrm{C}_{\mathrm{ha}}$. The cells were incubated for 16 and $32 \mathrm{~h}$. After the appropriate incubation period, the HeLa cells were trypsinized for $10 \mathrm{~min}$, re-suspended in phosphatebuffered saline (PBS) and transferred to polypropylene tubes. The Coulter DNA Prep reagents kit was used for DNA cell cycle analysis, as per the manufacturer's instructions. Briefly, $100 \mu 1$ lysis reagent were added to each tube and incubated for $5 \mathrm{~min}$ at room temperature. Thereafter, $500 \mu \mathrm{l} \mathrm{PI}(50 \mu \mathrm{g} / \mathrm{ml})$ were added and the tubes were incubated for $15 \mathrm{~min}$ at $37^{\circ} \mathrm{C}$. Flow cytometric analysis was performed directly following incubation. A Beckman Coulter Cytomics FC500 was used for all flow cytometricanalysis. FlowJo_V10 was used for analysis.

Analysis of mitochondrial membrane potential (MMP). A total of $300 \mu \mathrm{l}$ aliquots of trypsinized cells used for cell cycle analysis was removed from its respective culture dish and placed in a separate polypropylene tube for the analysis of MMP. The cells were centrifuged at $500 \mathrm{x} g$ for $5 \mathrm{~min}$ at room temperature and washed with PBS to remove the trypsin. Thereafter, a lipophilic cation dye, JC-1, was added to a final concentration of $2 \mu \mathrm{g} / \mathrm{ml}$. JC-1 was used to determine a change in the MMP. Cells were incubated for $10 \mathrm{~min}$ at room temperature in the dark. The cells were washed using $500 \mu \mathrm{l}$ PBS and centrifuged at $500 \mathrm{x} \mathrm{g}$ for $5 \mathrm{~min}$. The wash step was repeated three times prior to flow cytometric analysis.

Statistical analysis. Data are presented as the means \pm standard deviation (SD) from at least three independent experiments. Statistical significance was established by the Student's t-test at the level of $p<0.05$. The statistical significance of the differences between means was assessed by ANOVA with Tukey's post-hoc tests. P-values $<0.05$ were considered to indicate statistically significant differences.

The lethality percentage ( $\mathrm{L} \%$ ) was plotted against the logarithm of concentrations and the lethality, concentration curves were drawn using the least squares fit method and the lethal concentrations that kill $50 \%$ of organisms $\left(\mathrm{LC}_{50}\right)$ were determined using these curves. The upper and lower limits of the $95 \%$ confidence interval (CI 95\%) and the correlation coefficient $\left(r^{2}\right)$ were also calculated. 
Table I. Yield extraction, TFC and TPC for the Fallopia extracts.

\begin{tabular}{|c|c|c|c|c|}
\hline No. & Extract & $\begin{array}{l}\text { Yield of crude } \\
\text { extract }(\%)\end{array}$ & $\begin{array}{c}\text { TFC } \\
\text { (mg Q equiv./g DM) }\end{array}$ & $\begin{array}{c}\text { TPC } \\
\text { (mg GAE equiv./g DN }\end{array}$ \\
\hline 1 & $\begin{array}{l}\text { F. convolvulus } \\
\text { (hydroethanolic } 50 \%-\mathrm{C}_{\mathrm{ha}} \text { ) }\end{array}$ & 18.31 & $33.43 \pm 0.3510$ & $209.24 \pm 2.7899$ \\
\hline 2 & $\begin{array}{l}\text { F. dumetorum } \\
\text { (hydroethanolic } 50 \%-\mathrm{D}_{\mathrm{ha}} \text { ) }\end{array}$ & 10.21 & $22.73 \pm 0.3405$ & $77.44 \pm 0.8382$ \\
\hline 3 & $\begin{array}{l}\text { F. aubertii herba } \\
\text { (hydroethanolic } 50 \%-\mathrm{AH}_{\text {ha }} \text { ) }\end{array}$ & 13.65 & $30.02 \pm 0.3214$ & $162.33 \pm 4.8745$ \\
\hline 4 & $\begin{array}{l}\text { F. aubertii flores } \\
\text { (hydroethanolic } 50 \%-\mathrm{AF}_{\mathrm{ha}} \text { ) }\end{array}$ & 18.28 & $29.57 \pm 0.8453$ & $252.96 \pm 6.4306$ \\
\hline 5 & $\begin{array}{l}\text { F. aubertii flores } \\
\text { (aqueous }-\mathrm{AF}_{\mathrm{w}} \text { ) }\end{array}$ & 23.05 & $23.43 \pm 0.3831$ & $154.85 \pm 4.8467$ \\
\hline 6 & $\begin{array}{l}\text { F. aubertii flores } \\
\left(\text { ethanol } 96 \%-\mathrm{AF}_{\mathrm{e}}\right)\end{array}$ & 12.82 & $48.33 \pm 0.7122$ & $207.04 \pm 1.6670$ \\
\hline
\end{tabular}

Values are the means \pm standard deviation of triplicate analyses. GAE, gallic acid; TFC, total flavonoid content; Q, quercetin; TPC, total phenolic content; DM, dry plant material. Superscript letters e, ha and w indicate the solvent used i.e., $96 \%$ ethanol, 50\% ethanol or w, water, respectively.

Cell viability data and the $\mathrm{IC}_{50}$ values were calculated from the concentration-response data using a mathematical Hill function. All calculations were performed using GraphPad Prism version 5.0 software (GraphPad Software, Inc., La Jolla, CA, USA).

\section{Results and Discussion}

The present study focused on the cytotoxic effects of some extracts of $F$. convolvulus, $F$. dumetorum and $F$. aubertii on human cancer cell lines (MCF7, Caco-2 and HeLa) in correlation with their content in flavonoids and phenolic compounds. Additionally, the toxicity of the extracts was assessed by alternative toxicity bioassays using an in vitro model with confluent African green monkey kidney (Vero) cells and two in vivo invertebrate models, Artemia salina and Daphnia magna bioassays.

Extraction yield. Several steps such as milling, grinding, homogenization and extraction are required in order to obtain pharmacological active extracts from plant material (40). Extraction efficiency is affected by all these factors in different ways. Under the same conditions (e.g., particle size, temperature, extraction time, solvent:plant material ratio), the solvent and plant material composition are the most important parameters (41). In this study, we obtained six extracts from three plant species of the genus Fallopia. As F. convolvulus and F. dumetorum have a high TFC and TPC $(42,43)$, we prepared only the hydroethanolic $50 \%$ extract $\left(\mathrm{C}_{\mathrm{ha}}\right.$ and $\left.\mathrm{D}_{\mathrm{ha}}\right)$. From $F$. aubertii, four extracts were obtained: one from stems and leaves extracted with ethanol 50\% $\left(\mathrm{AH}_{\mathrm{ha}}\right)$ and three extracts from flowers with water $\left(\mathrm{AF}_{\mathrm{w}}\right)$, ethanol $50 \%\left(\mathrm{AF}_{\mathrm{ha}}\right)$ and ethanol $96 \%\left(\mathrm{AF}_{\mathrm{e}}\right)$. The extraction yields are presented in Table I. The extraction yields ranged from 10.2 to $23.5 \%$. $\mathrm{AF}_{\mathrm{w}}$ exhibited the highest yield compared to all other extracts, possibly due to the mucilage and other compounds soluble in water. The lowest extraction yield was obtained with ethanol $96 \%$. The results are in agreement with the extraction yields obtained for other medicinal plants rich in flavonoids (44).

Determination of TPC and TFC. Polyphenols are widespread compounds in plant species. Recent studies have reported a positive correlation between TPC/TFC and anticancer properties and have also shown the various mechanisms of action of these compounds in both in in vitro and in vivo models of cancer $(45,46)$. The TPC of the six different extracts was determined from a linear gallic acid (GAE) standard curve $\left(\mathrm{y}=0.1053 \mathrm{x}+0.0320, \mathrm{r}^{2}=0.9993\right)$ and the TFC was determined from a linear quercetin standard curve $(\mathrm{y}=0.0765 \mathrm{x}-0.0084$, $\left.r^{2}=0.9997\right)$. The TPC and TFC of the tested extracts are presented in Table I. The TPC in the tested extracts ranged from 77.44 to $252.96 \mathrm{mg}$ GA equiv./g DM. $\mathrm{AF}_{\text {ha }}$ showed the highest TPC among all the extracts. The decreasing order of the TPC in the extracts was: $\mathrm{AF}_{\mathrm{ha}}>\mathrm{C}_{\mathrm{ha}}>\mathrm{AF}_{\mathrm{e}}>\mathrm{AH}_{\mathrm{ha}}>\mathrm{AF}_{\mathrm{w}}>\mathrm{D}_{\mathrm{ha}}$. All results were statistically significant (ANOVA, $\mathrm{p}<0.0001$ ). However, the Tukey post-hoc $(\mathrm{p}<0.05)$ test revealed no differences between the TPC of $\mathrm{C}_{\mathrm{ha}}$ and $\mathrm{AF}_{\mathrm{e}}$. In addition, no signficant difference was observed in the TPC between $\mathrm{AH}_{\mathrm{ha}}$ and $\mathrm{AF}_{\mathrm{w}}(\mathrm{p}>0.05)$.

The TFC in the six extracts ranged from 22.73 to $48.33 \mathrm{mg} \mathrm{Q}$ equiv./g DM. The highest TFC was exhibited by $\mathrm{AF}_{\mathrm{e}}$. Ethanol $96 \%$ was the best solvent for the extraction of flavonoids for the $F$. aubertii flowers. The result is statistically significant $(\mathrm{p}<0.05)$ by comparison with the extraction with water and ethanol $50 \%$ of the same plant material. The decreasing order of the TFC in the extracts was: $\mathrm{AF}_{\mathrm{e}}>\mathrm{C}_{\mathrm{ha}}>\mathrm{AH}_{\mathrm{ha}}>\mathrm{AF}_{\mathrm{ha}}>\mathrm{AF}_{\mathrm{w}}>\mathrm{D}_{\mathrm{ha}}$. All the results were statistically significant (ANOVA, $\mathrm{p}<0.0001$ ). According to the Tukey range test $(\mathrm{p}<0.05)$, the TFC value was statistically similar for 

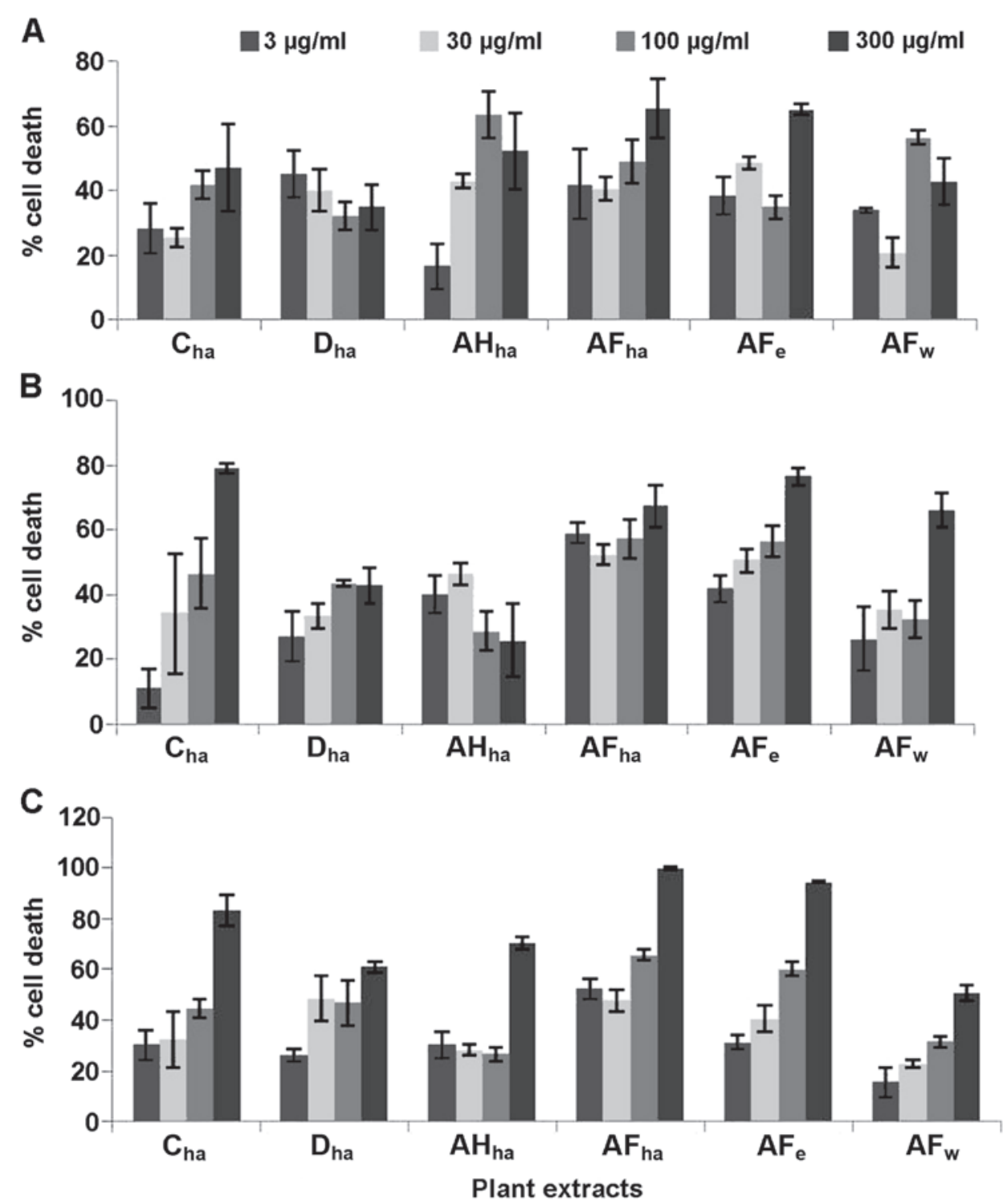

Figure 1. Initial screening of Fallopia extracts against a (A) cervical cancer cell line (MCF7), (B) colon carcinoma cell line (Caco-2) and (C) cervical cancer cell line (HeLa) at the concentrations indicated.

the herba and flores hydroalcoholic extracts of F. aubertii. Both the TPC and TFC were the lowest in $\mathrm{D}_{\text {ha }}$. Among the three species, F. aubertii exhibited the highest TPC and TFC.

\section{Assessment of cytotoxicity in vitro}

Initial screening of the extracts for their cytotoxic potential. Six Fallopia extracts were screened at 4 different concentrations, namely 3, 30, 100 and $300 \mu \mathrm{g} / \mathrm{ml}$ against the HeLa, Caco-2 and MCF7 cells (Fig. 1) for the determination of their cytotoxic potential. Based on these results, dose-response analysis was performed on the extracts $\mathrm{AF}_{\mathrm{ha}}, \mathrm{AF}_{\mathrm{e}}, \mathrm{C}_{\mathrm{ha}}$ and $\mathrm{D}_{\mathrm{ha}}$.

Dose-response analysis and $\mathrm{IC}_{50}$ determination. The cytotoxic effect of the four extracts was determined against the HeLa cells by MTT assay and teh $\mathrm{IC}_{50}$ values were determined. From these results, the concentration of the extracts to be used for further experiments was fixed at $125 \mu \mathrm{g} / \mathrm{ml}$ for $\mathrm{C}_{\mathrm{ha}}$ and $\mathrm{AF}_{\mathrm{e}}$ and at $100 \mu \mathrm{g} / \mathrm{ml}$ for $\mathrm{AF}_{\text {ha }}$ (Table II). The $\mathrm{IC}_{50}$ value of $\mathrm{D}_{\mathrm{ha}}$ was considered too high to pursue its cytotoxic potential. Cytotoxic evaluation was also performed using confluent African green monkey kidney (Vero) cells as a control cell line. All four extracts proved to be non-toxic to the Vero cells (data not shown).

Cell cycle analysis. DNA cell cycle analysis was performed using the HeLa cells after 16 and $32 \mathrm{~h}$ of exposure to 3 cytotoxic plant extracts. After $16 \mathrm{~h}$ of exposure (Fig. 2), a significant increase in the $\mathrm{G} 2 / \mathrm{M}$ population was evident for the $\mathrm{AF}_{\mathrm{ha}}$ and $\mathrm{C}_{\mathrm{ha}}$ extracts. After $16 \mathrm{~h}$, more than half the cell population treated with $\mathrm{AF}_{\mathrm{e}}$ experienced cell death (subG1). After $32 \mathrm{~h}$ of extract exposure (Fig. 3), a significant increase in the subG1 cell population was evident with all extracts.

Figs. 2 and 3 show cell cycle analysis used to determine which phase of the cell cycle cells arrest in. It is evident in Fig. 2 that after $16 \mathrm{~h}$ of exposure to $\mathrm{AF}_{\mathrm{ha}}$ and $\mathrm{C}_{\mathrm{ha}}$, the cells experienced G2/M phase arrest as there was a significant increase in $4 \mathrm{~N}$ DNA. After $16 \mathrm{~h}$ of treatment with $\mathrm{AF}_{\mathrm{e}}$, there was a marked increase in the subG1 peak, indicating apoptotic cells. This peak indicates the presence of fragmented DNA, 
Table II. $\mathrm{IC}_{50}$ of cytotoxicity to HeLa cells and dose-response curve parameters.

\begin{tabular}{|c|c|c|c|}
\hline Extract & $\begin{array}{c}\mathrm{IC}_{50} \\
(\mu \mathrm{g} / \mathrm{ml})\end{array}$ & $\begin{array}{c}\mathrm{IC} 95 \% \text { of } \mathrm{IC}_{50} \\
(\mu \mathrm{g} / \mathrm{ml})\end{array}$ & $\begin{array}{l}\text { Goodness of fit } \\
\qquad\left(\mathrm{r}^{2}\right)\end{array}$ \\
\hline $\begin{array}{l}\text { F. aubertiiflores } \\
\text { (hydroethanolic } 50 \%-\mathrm{AF}_{\mathrm{ha}} \text { ) }\end{array}$ & $106.0 \pm 5.94$ & $96.0-138.2$ & 0.9593 \\
\hline $\begin{array}{l}\text { F. aubertii flores } \\
\left(\text { ethanol } 96 \%-\mathrm{AF}_{\mathrm{e}}\right)\end{array}$ & $124.7 \pm 8.91$ & ND & 0.9453 \\
\hline $\begin{array}{l}\text { F. convolvulus } \\
\text { (hydroethanolic } 50 \%-\mathrm{C}_{\mathrm{ha}} \text { ) }\end{array}$ & $122.9 \pm 6.98$ & $112.9-142.0$ & 0.9751 \\
\hline $\begin{array}{l}\text { F. dumetorum } \\
\text { (hydroethanolic } 50 \%-\mathrm{D}_{\mathrm{ha}} \text { ) }\end{array}$ & ND & ND & 0.5157 \\
\hline
\end{tabular}

ND, not determined. Superscript letters e, ha and w indicate the solvent used i.e., $96 \%$ ethanol, $50 \%$ ethanol or w, water, respectively.
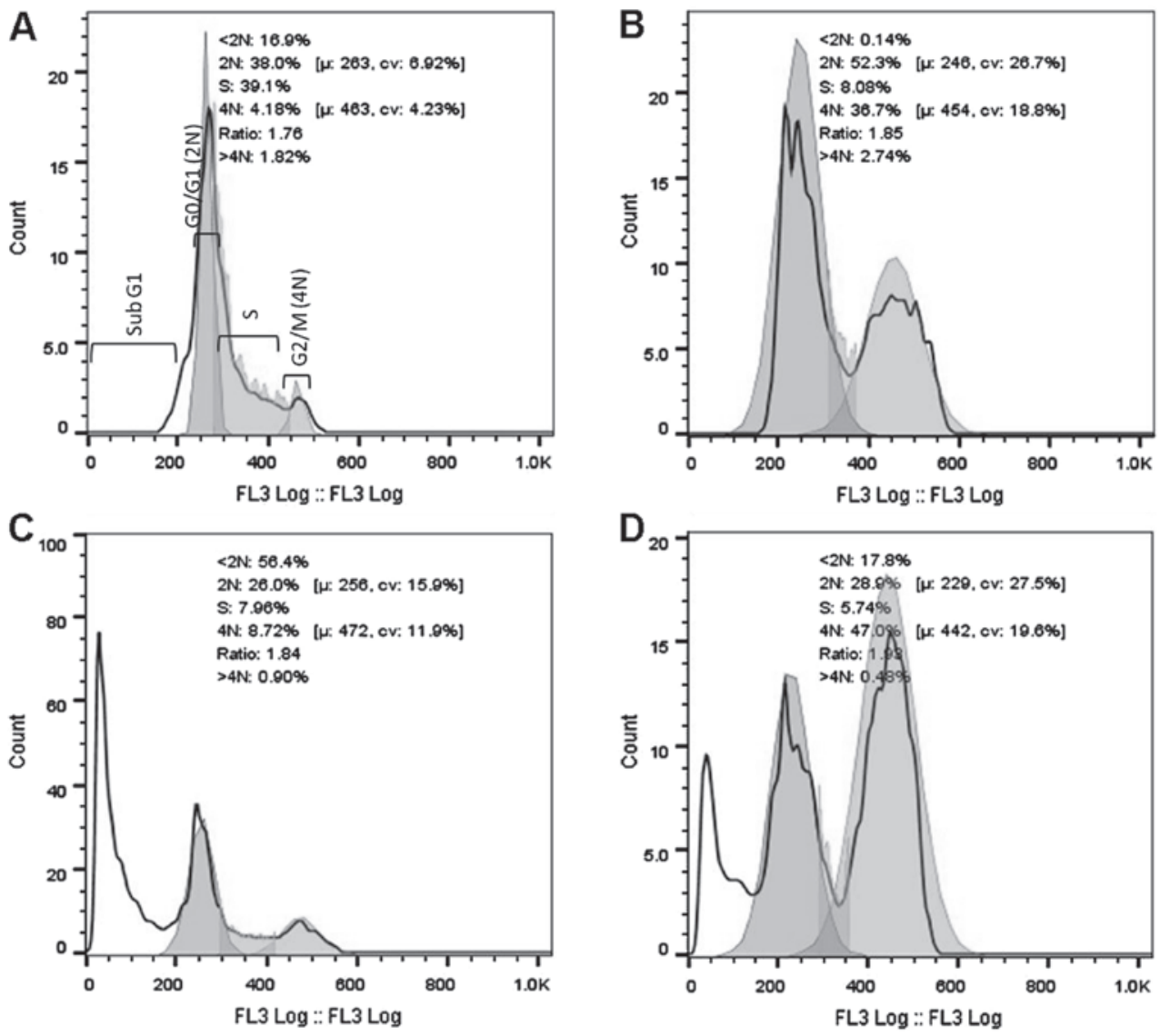

Figure 2. Histograms representing DNA cell cycle analysis after $16 \mathrm{~h}$ of treatment of the cervical cancer cells (HeLa cells). HeLa cells were treated with (B) $100 \mu \mathrm{g} / \mathrm{ml} \mathrm{AF}_{\mathrm{ha}}$, (C) $125 \mu \mathrm{g} / \mathrm{ml} \mathrm{AF}_{\mathrm{e}}$ and (D) $125 \mu \mathrm{g} / \mathrm{ml} \mathrm{C}_{\mathrm{ha}}$. (A) Represents untreated control cell population. Cell cycle analysis was performed on a Beckman Coulter Cytomics FC500 flow cytometer following propidium iodide (PI) staining of DNA. FlowJo V10 was used for analysis of results. Ten thousand events were recorded for each sample.

a biochemical hallmark of apoptosis. After $32 \mathrm{~h}$ of treatment with the plant extracts, a marked increase in the subG1 cell population was evident, suggesting that the cells were apoptotic.

The mechanism of this $\mathrm{G} 2 / \mathrm{M}$ arrest cannot be deduced from propidium iodide (PI) cell cycle analysis and more than one possibility exists. $\mathrm{Cdc} 25 \mathrm{~B}$ and $\mathrm{Cdc} 25 \mathrm{C}$ are phosphatases that regulate the progression of the cell cycle from the $\mathrm{G} 2$ phase through to the $\mathrm{M}$ phase. They do so by their activity on $\mathrm{Cdc} 2 /$ cyclin A and Cdc2/cyclin B complexes (47). Active Cdc2 complexed to cyclin B1 is required for the progression from the $\mathrm{G} 2$ to the M phase. When DNA damage occurs, Cdc25C is deactivated by a cascade process and this results in the phosphorylation and hence, the inactivity of $\mathrm{Cdc} 2 /$ cyclin $\mathrm{B}$ and thus arrest of the cell cycle in the G2 phase. G2/M arrest can also occur by problems in the formation of the mitotic spindle and 

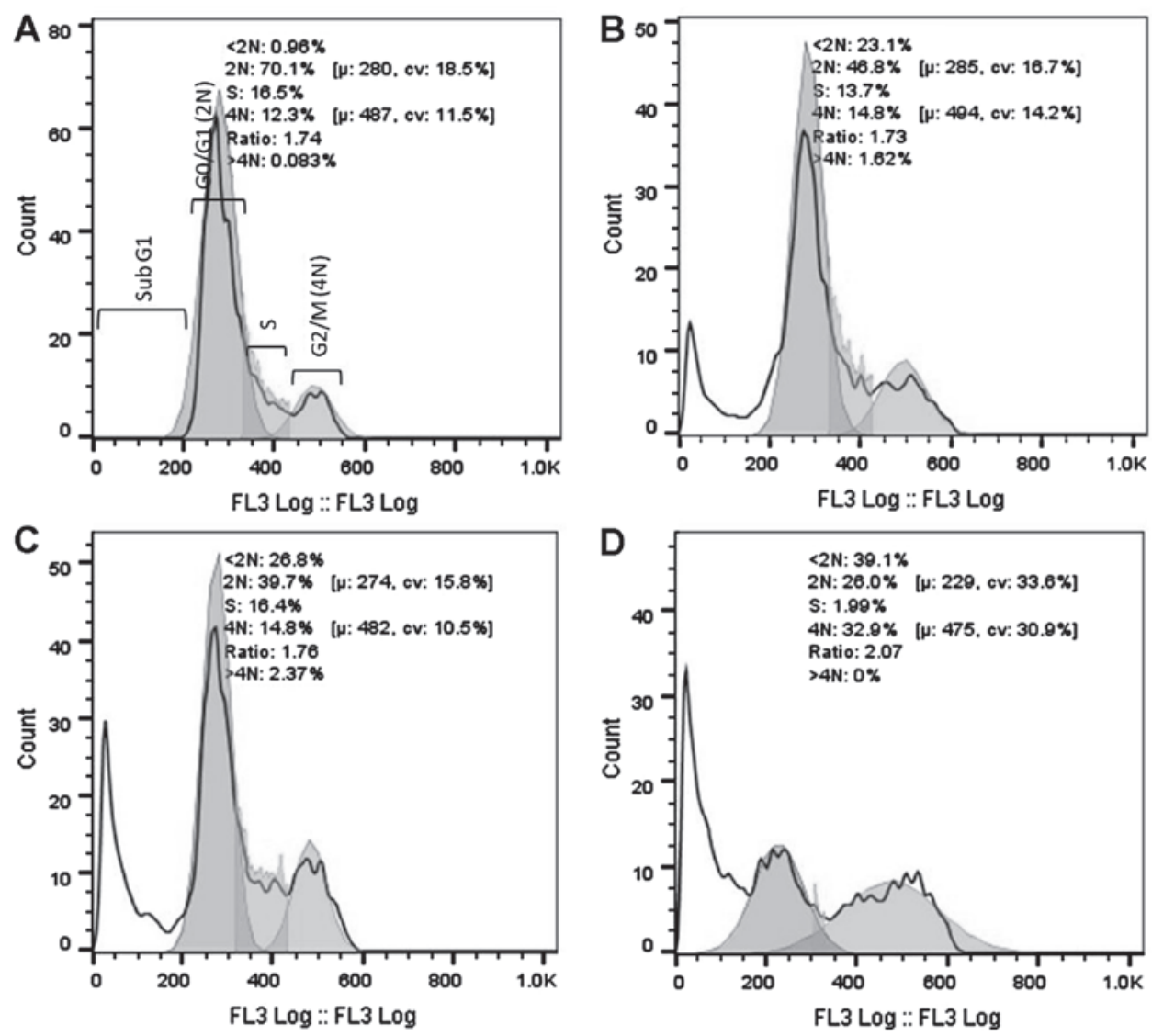

Figure 3. Histograms representing DNA cell cycle analysis after $32 \mathrm{~h}$ of treatment of cervical cancer cells (HeLa cells). HeLa cells were treated with (B) $100 \mu \mathrm{g} / \mathrm{ml}$ $\mathrm{AF}_{\text {ha }}$, (C) $125 \mu \mathrm{g} / \mathrm{ml} \mathrm{AF}$ and (D) $125 \mu \mathrm{g} / \mathrm{ml} \mathrm{C}_{\mathrm{ha}}$. (A) Represents untreated control cell population. Cell cycle analysis was done on a Beckman Coulter Cytomics FC500 flow cytometer following propidium iodide (PI) staining of DNA. FlowJo V10 was used for analysis of results. Ten thousand events were recorded for each sample.

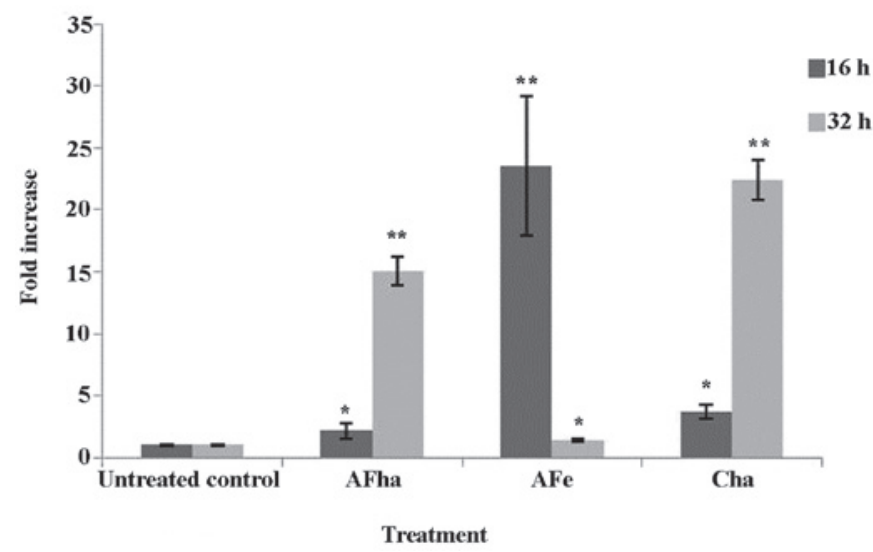

Figure 4. Fold increase in mean green fluorescence intensity indicating the depolarization of the mitochondria after 16 and $32 \mathrm{~h}$ of treatment of cervical cancer cells (HeLa cells). Analysis was performed using a Beckman Coulter Cytomics FC500 flow cytometer following JC-1 staining. Ten thousand events were recorded for each sample. Error bars indicate the SD of triplicate values of a single experiment. Significance was determined using the Student's t-test, " $\mathrm{p}<0.05$ and ${ }^{* *} \mathrm{p}<0.005$.

this results in mitotic catastrophe (47). Further studies on the mechanisms of G2/M arrest need to be performed by evaluating the state and levels of $\mathrm{Cdc} 2$ and cyclin B proteins, as well as Cdc25C phosphatase. The effects of the plant extracts on tubulin polymerization also need to be determined.
After $16 \mathrm{~h}$ of treatment with $\mathrm{AF}_{\mathrm{e}}$, the HeLa cells experienced a significant increase in cell death, as indicated by the large subG1 peak. It is thought that cell cycle arrest may have occurred earlier than $16 \mathrm{~h}$ and thus was not seen. In order to determine whether cells experience cell cycle arrest, the analysis of the DNA state can be performed at an earlier time interval.

Evaluation of MMP. To determine the onset of the intrinsic pathway of apoptosis, the MMP was evaluated using the lipophilic cationic dye, JC-1. This dye reversibly changes the colour from green to orange as the membrane potential of the mitochondria increases. Thus, an increase in the mean green fluorescence intensity (MFI) would indicate the depolarization of the mitochondrial membranes and hence the involvement of the mitochondria in the induction of apoptosis.

An increase in the MFI in the green channel was evident after $16 \mathrm{~h}$, but more evidently at $32 \mathrm{~h}$ of exposure to the $\mathrm{AF}_{\mathrm{ha}}$ and $\mathrm{C}_{\mathrm{ha}}$ extracts (Fig. 4).

Cytotoxic stimuli may induce the permeabilization of cellular membranes and result in the depolarization of the mitochondrial membrane. A method to determine changes in the MMP is by using JC-1. JC-1 forms aggregates when present in high concentrations and the aggregates fluoresce orange (48). If J-aggregates do not form and the dye exists as monomers due to depolarization of the mitochondrial membrane, an increase in green fluorescence will be evident. 
Table III. Acute toxicity of the extracts to AS and on DM.

\begin{tabular}{|c|c|c|c|c|c|c|c|}
\hline \multirow[b]{2}{*}{ No. } & \multirow[b]{2}{*}{ Extract } & \multicolumn{2}{|c|}{$\begin{array}{c}\mathrm{LC}_{50} \\
(\mu \mathrm{g} / \mathrm{ml})\end{array}$} & \multicolumn{2}{|c|}{$\begin{array}{l}\text { CI } 95 \% \text { of } \mathrm{LC}_{50} \\
(\mu \mathrm{g} / \mathrm{ml})\end{array}$} & \multicolumn{2}{|c|}{$\begin{array}{l}\text { Goodness of fit } \\
\left(\mathrm{r}^{2}\right)\end{array}$} \\
\hline & & AS & $\mathrm{DM}$ & AS & $\mathrm{DM}$ & AS & $\mathrm{DM}$ \\
\hline 1. & $\begin{array}{l}\text { F. convolvulus } \\
\text { (hydroethanolic } 50 \%-\mathrm{C}_{\mathrm{ha}} \text { ) }\end{array}$ & ND & ND & ND & ND & 0.8524 & ND \\
\hline 2. & $\begin{array}{l}\text { F. dumetorum } \\
\text { (hydroethanolic } 50 \% \text { - } \mathrm{D}_{\text {ha }} \text { ) }\end{array}$ & 2689.09 & 4073.80 & 2664.09-2714.96 & ND & 0.9969 & 0.8769 \\
\hline 3. & $\begin{array}{l}\text { F. aubertii herba } \\
\text { (hydroethanolic } 50 \%-\mathrm{AH}_{\text {ha }} \text { ) }\end{array}$ & 2576.36 & 2884.03 & $2503.18-2888.15$ & ND & 0.9865 & 0.8996 \\
\hline 4. & $\begin{array}{l}\text { F. aubertii flores } \\
\text { (hydroethanolic } 50 \%-\mathrm{AF}_{\text {ha }} \text { ) }\end{array}$ & 2374.70 & 2398.83 & $2222.08-2522.71$ & $2344.22-2454.71$ & 0.9471 & 0.9847 \\
\hline 5. & $\begin{array}{l}\text { F. aubertii flores } \\
\left(\text { aqueous }-\mathrm{AF}_{\mathrm{w}} \text { ) }\right.\end{array}$ & 2239.55 & 3019.95 & 2186.19-2293.30 & ND & 0.9913 & 0.9399 \\
\hline 6. & $\begin{array}{l}\text { F. aubertii flores } \\
\text { (ethanol } 96 \%-\mathrm{AF}_{\mathrm{e}} \text { ) }\end{array}$ & 1872.16 & 2951.20 & $1802.54-1939.97$ & $\mathrm{ND}$ & 0.9889 & 0.9266 \\
\hline 7 & Colchicine & 1.45 & 4.74 & $1.24-1.69$ & $4.50-4.98$ & 0.9483 & 0.9880 \\
\hline
\end{tabular}

ND, not determined (the value could not be calculated); AS, Artemia salina; DM, Daphnia magna.

Fig. 4 shows a significant fold increase in green MFI after $16 \mathrm{~h}$ of exposure to $\mathrm{AF}_{\mathrm{e}}$ and after $32 \mathrm{~h}$ of exposure to $\mathrm{AF}_{\mathrm{ha}}$ and $\mathrm{C}_{\mathrm{ha}}$. This suggests that the mitochondria are depolarized due to exposure to the extracts and that the intrinsic pathway of apoptosis is activated.

Once the MMP decreases, proteins that are normally found between the inner and outer membrane of the mitochondria are then released and promote the activation of the apoptotic cascades (49).

Assessment of acute toxicity. The assessment of toxicity using alternative methods (e.g., Artemia salina and Daphnia magna bioassays) is widely used due to the many advantages as being inexpensive, time saving and having a high degree of correlation with the acute toxicity $\left(\mathrm{LC}_{50}\right)$ registered in pharmacotoxicology studies on rodents (mice and rats) mammalian models (50-52).

None of the tested extracts were toxic to both the Artemia salina and Daphnia magna invertebrates. The extracts were first tested in the range of 10 to $1000 \mu \mathrm{g} / \mathrm{ml}[10,50,100$, $250,500,750$ and $1,000 \mu \mathrm{g} / \mathrm{ml}$, and no toxicity was observed ( $\mathrm{L} \%<0.05)$ at all tested concentrations]. In order to assess the toxicity at higher concentrations, another experiment was carried out at concentrations between 1,000 and 3,000 $\mu \mathrm{g} / \mathrm{ml}$. $\mathrm{LC}_{50}$ were calculated only at $24 \mathrm{~h}$ of exposure due to the lack of information concerning the stability of the extracts and as the extracts tend to precipitate in aqueous DMSO solutions in the second day of the experiments.The brine shrimp lethality test revealed toxic effects only at high concentrations of the extracts from $F$. dumetorum and $F$. aubertii. The $\mathrm{LC}_{50}$ exhibited by the five extracts ranged from 1872.16 to $2689.09 \mu \mathrm{g} / \mathrm{ml}$ (Table III). Although the $\mathrm{LC}_{50}$ could be calculated, we consider that the extracts did not present any toxic risk at all. Their toxicity to A. salina was far below the limit of $1,000 \mu \mathrm{g} / \mathrm{ml}$ mentioned by Meyer et al (37). A positive correlation between the concentration and lethality was observed for all six extracts $\left(r^{2}>0.85\right)$. With the exception of $\mathrm{C}_{\mathrm{Et} 50}$, no significant differences were observed $(\mathrm{p}<0.05)$. In comparison with the positive control, all $\mathrm{LC}_{50}$ values are at least 1,000 -fold higher, thus the toxicity is significantly lower or non-existent. $\mathrm{LC}_{50}$ induced by $F$. convolvulus extract could not be calculated because of a lethality $<35 \%$ exhibited at the maximum concentration.

The absence of toxicity observed in the brine shrimp lethality test was supported by results of the D. magna bioassay. The $\mathrm{LC}_{50}$ exhibited by the extracts on the daphnids ranged from 2398.83 to $4073.80 \mu \mathrm{g} / \mathrm{ml}$ (Table III). A positive correlation between the concentration and lethality $\left(r^{2}>0.85\right)$ and no statistical differences were observed for the determinations performed with the $F$. dumetorum and $F$. aubertii extracts $(\mathrm{p}<0.05) . F$. convolvulus exhibited no toxicity at all on Daphnia magna, the L\% induced by the extract at 3,000 $\mu \mathrm{g} / \mathrm{ml}$ being $<5 \%$. All results were significantly higher than the positive control $(4.74 \mu \mathrm{g} / \mathrm{ml})$ and the toxicity threshold reported by Guilhermino et al (50) for toxic substances.

In conclusion, of the three species of Fallopia investigated in this study, none was significantly toxic to invertebrate models or to the normal cell model. The highest cytotoxicity to the cancer cells was observed with extracts from the $F$. convolvulus and $F$. aubertii flowers. There was a positive correlation between TPC of the extracts and the $\mathrm{IC}_{50}$ values against $\mathrm{HeLa}$ cervical cancer cells, with $F$. aubertii flower hydroethanolic extract $\left(\mathrm{AF}_{\mathrm{ha}}\right)$ having the highest TPC content and the lowest $\mathrm{IC}_{50}$. This extract also induced apoptosis at a much earlier time point than the two extracts with the second and third highest 
TPC values, namely $F$. convolvulus hydroethanolic extract $\left(\mathrm{C}_{\mathrm{ha}}\right)$ and $F$. aubertii flower ethanolic extract $\left(\mathrm{AF}_{\mathrm{e}}\right)$, respectively.

\section{Acknowledgements}

The authors acknowledge the financial support offered by 'Carol Davila' University of Medicine and Pharmacy Bucharest, through research grant no. 33883/11.11.2014. The authors are thankful to PhD Carmen Petronela Comanescu ('Dimitrie Brandza' Botanical Garden, Bucharest) for her technical assistance in plants' identification.

\section{References}

1. Ridge CA, McErlean AM and Ginsberg MS: Epidemiology of lung cancer. Semin Intervent Radiol 30: 93-98, 2013.

2. Baili P, Hoekstra-Weebers J, Van Hoof E, Bartsch HH, Travado L, Garami M, Di Salvo F, Micheli A and Veerus P; EUROCHIP-3 Working group on Cancer Rehabilitation: Cancer rehabilitation indicators for Europe. Eur J Cancer 49: 1356-1364, 2013.

3. Ferlay J, Steliarova-Foucher E, Lortet-Tieulent J, Rosso S, Coebergh JW, Comber H, Forman D and Bray F: Cancer incidence and mortality patterns in Europe: Estimates for 40 countries in 2012. Eur J Cancer 49: 1374-1403, 2013.

4. Orlikova B and Diederich M: Power from the garden: Plant compounds as inhibitors of the hallmarks of cancer. Curr Med Chem 19: 2061-2087, 2012.

5. Gordaliza M: Natural products as leads to anticancer drugs. Clin Transl Oncol 9: 767-776, 2007

6. Karikas GA: Anticancer and chemopreventing natural products: Some biochemical and therapeutic aspects. J BUON 15: 627-638, 2010.

7. Tan G, Gyllenhaal C and Soejarto DD: Biodiversity as a source of anticancer drugs. Curr Drug Targets 7: 265-277, 2006.

8. Singh M, Kaur M and Silakari O: Flavones: An important scaffold for medicinal chemistry. Eur J Med Chem 84: 206-239, 2014.

9. Wu B, Zhang Q, Shen W and Zhu J: Anti-proliferative and chemosensitizing effects of luteolin on human gastric cancer AGS cell line. Mol Cell Biochem 313: 125-132, 2008.

10. Sak K: Cytotoxicity of dietary flavonoids on different human cancer types. Pharmacogn Rev 8: 122-146, 2014.

11. Patil JR, Chidambara Murthy KN, Jayaprakasha GK, Chetti MB and Patil BS: Bioactive compounds from Mexican lime (Citrus aurantifolia) juice induce apoptosis in human pancreatic cells. J Agric Food Chem 57: 10933-10942, 2009.

12. Russo P, Del Bufalo A and Cesario A: Flavonoids acting on DNA topoisomerases: Recent advances and future perspectives in cancer therapy. Curr Med Chem 19: 5287-5293, 2012.

13. Tu SH, Ho CT, Liu MF, Huang CS, Chang HW, Chang CH, $\mathrm{Wu} \mathrm{CH}$ and Ho YS: Luteolin sensitises drug-resistant human breast cancer cells to tamoxifen via the inhibition of cyclin E2 expression. Food Chem 141: 1553-1561, 2013.

14. Kuntz S, Wenzel U and Daniel H: Comparative analysis of the effects of flavonoids on proliferation, cytotoxicity, and apoptosis in human colon cancer cell lines. Eur J Nutr 38: 133-142, 1999.

15. Mojzis J, Varinska L, Mojzisova G, Kostova I and Mirossay L: Antiangiogenic effects of flavonoids and chalcones. Pharmacol Res 57: 259-265, 2008.

16. Hou D-X and Kumamoto T: Flavonoids as protein kinase inhibitors for cancer chemoprevention: Direct binding and molecular modeling. Antioxid Redox Signal 13: 691-719, 2010.

17. Syed DN, Adhami VM, Khan MI and Mukhtar H: Inhibition of Akt/mTOR signaling by the dietary flavonoid fisetin. Anticancer Agents Med Chem 13: 995-1001, 2013.

18. Kong D, Zhang Y, Yamori T, Duan H and Jin M: Inhibitory activity of flavonoids against class I phosphatidylinositol 3-kinase isoforms. Molecules 16: 5159-5167, 2011.

19. Dai J and Mumper RJ: Plant phenolics: Extraction, analysis and their antioxidant and anticancer properties. Molecules 15: 7313-7352, 2010

20. Dolečková I, Rárová L, Grúz J, Vondrusová M, Strnad M and Kryštof V: Antiproliferative and antiangiogenic effects of flavone eupatorin, an active constituent of chloroform extract of Orthosiphon stamineus leaves. Fitoterapia 83: 1000-1007, 2012.
21. Kitdamrongtham W, Manosroi A, Akazawa H, Gidado A Stienrut P, Manosroi W, Lohcharoenkal W, Akihisa T and Manosroi J: Potent anti-cervical cancer activity: Synergistic effects of Thai medicinal plants in recipe N040 selected from the MANOSROI III database. J Ethnopharmacol 149: 288-296, 2013.

22. Holub J: Fallopia Adans. 1763 instead of Bilderdykia Dum. 1827. Folia Geobot Phytotaxon 6: 171-177, 1971.

23. Haraldson K: Anatomy and taxonomy in Polygonaceae subfam. Polygonoideae Meisn. emend. Jaretzky. Symb. Bot Upsal 22: $1-95,1978$.

24. Decraene LP and Akeroyd JR: Generic limits in Polygonum L. and related genera (Polygonaceae) on the basis of floral characters. J Linn Soc 98: 321-371, 1988.

25. Nielsen H and Steinar H: Fallopia Adans. In: Flora Nordica. Vol. 1: Lycopodiaceae to Polygonaceae. Jonsell B (ed). Bergius Foundation, Stockholm, pp273-278, 2000.

26. Song J, Yao H, Li Y, Li X, Lin Y, Liu C, Han J, Xie C and Chen S: Authentication of the family Polygonaceae in Chinese pharmacopoeia by DNA barcoding technique. J Ethnopharmacol 124: 434-439, 2009.

27. Tiébré MS, Bizoux JP, Hardy OJ, Bailey JP and Mahy G: Hybridization and morphogenetic variation in the invasive alien Fallopia (Polygonaceae) complex in Belgium. Am J Bot 94: 1900-1910, 2007

28. Kim M, Hee Park J and Park CC: Flavonoid chemistry of Fallopia section Fallopia (Polygonaceae). Biochem Syst Ecol 28: 433-441, 2000.

29. Kim MH, Park JH, Won H and Park CW: Flavonoid chemistry and chromosome numbers of Fallopia section Pleuropterus (Polygonaceae). Can J Bot 78: 1136-1143, 2000.

30. Smolarz HD: Comparative study on the free flavonoid aglycones in herbs of different species of Polygonum L. Acta Pol Pharm 59: 145-148, 2002

31. Zhang CF, Chen J, Zhao LQ, Zhang D, Zhang M and Wang ZT: Three new flavonoids from the active extract of Fallopia convolvulus. J Asian Nat Prod Res 13: 136-142, 2011.

32. Olaru OT, Anghel AI, Istudor V, Ancuceanu RV and Dinu M: Contributions to the pharmacognostical and phytobiological study of Fallopia aubertii (L. Henry) Holub. (Polygonaceae). Farmacia 61: 991-999, 2013

33. Zhao YM, Qi HY and Shi YP: Several chromones from the stems of Polygonum aubertii Henry. J Asian Nat Prod Res 12: 623-628, 2010.

34. González M, Guzmán B, Rudyk R, Romano E and Molina MA: Spectrophotometric determination of phenolic compounds in propolis. Lat Am J Pharm 22: 243-248, 2003.

35. Chang CC, Yang MH, Wen HM and Chern JC: Estimation of total flavonoid content in propolis by two complementary colometric methods. J Food Drug Anal 10: 178-182, 2002.

36. Bazylko A, Parzonko A, Jez W, Osińska E and Kiss AK: Inhibition of ROS production, photoprotection, and total phenolic, flavonoids and ascorbic acid content of fresh herb juice and extracts from the leaves and flowers of Tropaeolum majus. Ind Crops Prod 55: 19-24, 2014.

37. Meyer BN, Ferrigni NR, Putnam JE, Jacobsen LB, Nichols DE and McLaughlin JL: Brine shrimp: A convenient general bioassay for active plant constituents. Planta Med 45: 31-34, 1982.

38. Fan W, Cui M, Liu H, Wang C, Shi Z, Tan C and Yang X: Nano- $\mathrm{TiO}_{2}$ enhances the toxicity of copper in natural water to Daphnia magna. Environ Pollut 159: 729-734, 2011.

39. Nitulescu GM, Draghici C and Olaru OT: New potential antitumor pyrazole derivatives: Synthesis and cytotoxic evaluation. Int J Mol Sci 14: 21805-21818, 2013

40. Gong Y, Liu X, He WH, Xu HG, Yuan F and Gao YX: Investigation into the antioxidant activity and chemical composition of alcoholic extracts from defatted marigold (Tagetes erecta L.) residue. Fitoterapia 83: 481-489, 2012.

41. Ghitescu RE, Volf I, Carausu C, Bühlmann AM, Gilca IA and Popa VI: Optimization of ultrasound-assisted extraction of polyphenols from spruce wood bark. Ultrason Sonochem 22: 535-541, 2015.

42. Olaru OT, Ancuceanu RV, Anghel AI and Dinu M: Șeremet OC and Istudor V: Botanical investigation of Fallopia dumetorum (L.) Holub (Polygonaceae) and qualitative and quantitative assessment of its polyphenolic compounds. Acta Med Marisiensis 60: 67-71, 2014.

43. Olaru OT, Anghel AI, Istudor V and Olaru II: The qualitative and quantitative determination of the phenolic compounds in Polygonum convolvulus L. species, Polygonaceae family. Acta Med Marisiensis 59: 162-164, 2013. 
44. Sultana B, Anwar F and Ashraf M: Effect of extraction solvent/ technique on the antioxidant activity of selected medicinal plant extracts. Molecules 14: 2167-2180, 2009.

45. Sahpazidou D, Geromichalos GD, Stagos D, Apostolou A, Haroutounian SA, Tsatsakis AM, Tzanakakis GN, Hayes AW and Kouretas D: Anticarcinogenic activity of polyphenolic extracts from grape stems against breast, colon, renal and thyroid cancer cells. Toxicol Lett 230: 218-224, 2014.

46. Sun T, Chen QY, Wu LJ, Yao XM and Sun XJ: Antitumor and antimetastatic activities of grape skin polyphenols in a murine model of breast cancer. Food Chem Toxicol 50: 3462-3467, 2012.

47. Busino L, Chiesa M, Draetta GF and Donzelli M: Cdc25A phosphatase: Combinatorial phosphorylation, ubiquitylation and proteolysis. Oncogene 23: 2050-2056, 2004.

48. Smiley ST, Reers M, Mottola-Hartshorn C, Lin M, Chen A, Smith TW, Steele GD Jr and Chen LB: Intracellular heterogeneity in mitochondrial membrane potentials revealed by a J-aggregate-forming lipophilic cation JC-1. Proc Natl Acad Sci USA 88: 3671-3675, 1991.
49. Saelens X, Festjens N, Vande Walle L, van Gurp M, van Loo G and Vandenabeele P: Toxic proteins released from mitochondria in cell death. Oncogene 23: 2861-2874, 2004.

50. Guilhermino L, Diamantino T, Silva MC and Soares AM: Acute toxicity test with Daphnia magna: An alternative to mammals in the prescreening of chemical toxicity? Ecotoxicol Environ Saf 46: 357-362, 2000.

51. Hartl M and Humpf HU: Toxicity assessment of fumonisins using the brine shrimp (Artemia salina) bioassay. Food Chem Toxicol 38: 1097-1102, 2000.

52. Logarto Parra A, Silva Yhebra R, Guerra Sardiñas I and Iglesias Buela L: Comparative study of the assay of Artemia salina $\mathrm{L}$. and the estimate of the medium lethal dose (LD50 value) in mice, to determine oral acute toxicity of plant extracts. Phytomedicine 8: 395-400, 2001. 